\title{
Nitrogen, phosphorus and zinc enhance Maize hybrid productivity and build up soil phosphorus and zinc in Maize faba bean cropping system in semiarid region
}

\author{
Imranud Din* and Shad Khan Khalil
}

Department of Agronomy, University of Agriculture, Peshawar-Pakistan

*Corresponding author's email: imranuddin230@yahoo.com

Citation

Imranud Din and Shad Khan Khalil. Nitrogen, phosphorus and zinc enhance Maize hybrid productivity and build up soil phosphorus and zinc in Maize faba bean cropping system in semiarid region. Pure and Applied Biology. Vol. 5, Issue 4, pp1107-1119. http://dx.doi.org/10.19045/bspab.2016.50133

\begin{tabular}{llll}
\hline \hline Received: 19/08/2016 & Revised: 04/10/2016 & Accepted: 08/10/2016 & Online First: 18/10/2016 \\
\hline
\end{tabular}

\section{Abstract}

It is assumed that all of the applied nitrogen, phosphorus and zinc are not utilized by the current crop and may remain in the soil that could be used by succeeding crops. Aim of this study to evaluate the effect of nitrogen $(\mathrm{N})$ phosphorus $(\mathrm{P})$ and zinc $(\mathrm{Zn})$ on maize hybrid 3305 and soil $\mathrm{P}$ and Zn. A two years experiment was conducted at The University of Agriculture Peshawar, Pakistan in 2013-2014 to evaluate the impact of N, P and $\mathrm{Zn}$ on maize and soil $\mathrm{P}$ and $\mathrm{Zn}$ accumulation. Three levels of $\mathrm{N}\left(150,200\right.$ and $\left.250 \mathrm{~kg} \mathrm{ha}^{-1}\right), \mathrm{P}\left(75,125\right.$ and $\left.175 \mathrm{~kg} \mathrm{ha}^{-1}\right)$ and $\mathrm{Zn}$ $\left(5,10,15 \mathrm{~kg} \mathrm{ha}^{-1}\right)$ along with control were applied to maize. N, P and $\mathrm{Zn}$ significantly increased grains ear ${ }^{-1}(\mathrm{GE})$, thousand grains weight (TGW) and delayed days to silking (DS) compared with control. Grains ear ${ }^{-1}(\mathrm{GE})$, thousand grains weight (TGW) was significantly higher as compared to control. Each increment of N, P and $\mathrm{Zn}$ increased GE and TGW. Maximum GE and TGW were recorded at $250 \mathrm{~kg} \mathrm{~N} \mathrm{ha}^{-1}, 175 \mathrm{~kg} \mathrm{P} \mathrm{ha}^{-1}$ and $15 \mathrm{~kg} \mathrm{Zn} \mathrm{ha}^{-1}$ across both years. The DS was higher with $250 \mathrm{~kg} \mathrm{~N} \mathrm{ha}^{-1}, 75 \mathrm{~kg} \mathrm{P} \mathrm{ha}^{-1}$ and $15 \mathrm{~kg} \mathrm{Zn} \mathrm{ha}^{-1}$. Soil P content increased from $0.96 \mathrm{mg}$ $\mathrm{kg}^{-1}$ in control to $2.9 \mathrm{mg} \mathrm{kg}^{-1}$ in P and $\mathrm{Zn}$ fertilized plots, whereas $\mathrm{Zn}$ increased from $3.68 \mathrm{mg} \mathrm{kg}^{-1}$ in control to $6.58 \mathrm{mg} \mathrm{kg}^{-1}$ in $\mathrm{P}$ and $\mathrm{Zn}$ fertilized plots over 2 years. It is concluded that $250 \mathrm{~kg} \mathrm{~N}$ $\mathrm{ha}^{-1}, 175 \mathrm{~kg} \mathrm{P} \mathrm{ha}^{-1}$ and $15 \mathrm{~kg} \mathrm{Zn} \mathrm{ha}^{-1}$ resulted in better production of maize and increased soil $\mathrm{P}$ and $\mathrm{Zn}$ that could be utilized by succeeding crop.

Keywords: Nitrogen; Phosphorus; Zinc; Maize; Soil P and Zn

Introduction

Maize (Zia mays L) is used as food and feed for cattle [1]. It is utilized as raw material for starch, corn soup and corn flakes [2]. Maize grains composed of $70 \%$ starch, $4.8 \%$ oil, $10 \%$ protein, $13.2 \%$ fiber and $2 \%$ ash [3] Among other factors, indiscriminate applications of fertilizers including nitrogen, $\mathrm{P}$ and $\mathrm{Zn}$ are responsible for low yield [4]. Nitrogen $(\mathrm{N})$ is an essential element for plant growth and development, and is considered one of the main factors controlling productivity of cereal crops [5, 6]. $\mathrm{N}$ deficiency results in poor plant 
development and severe reduction in harvestable yield.

Phosphorus (P) is another essential macro nutrient present in the inorganic as well as organic forms in soil. It is a component of deoxyribonucleic acid (DNA) and ribonucleic acid (RNA), nucleus, cell division and heredity transmission. Plants absorb most of the $\mathrm{P}$ during vegetative growth, which is remobilized into the grains during grain filling stage [7]. It enhances early growth and root development $[8,9]$. However Phosphorus (P) availability is low in soil due to high concentration of $\mathrm{Caco}_{3}$ in the soil. $\mathrm{P}$ is the least available macronutrient in soil [10]. The application of $\mathrm{P}$ to the $\mathrm{P}$ deficit soil could increase maize production with superior quality [11]. Zinc $(\mathrm{Zn})$ is the $3^{\text {rd }}$ yield limiting nutrient after nitrogen and phosphorus [12]. $\mathrm{Zn}$ is the main component of the different enzymes which are responsible for the metabolism of carbohydrate, protein, and increases disease resistance in plant $[13,14]$. Zn enhances the synthesis of the enzyme which promotes chlorophyll formation [15]. Photosynthates productions in crops are also $\mathrm{Zn}$ dependent [16, 17]. Zn deficiency causes stunted growth, slow cell division, susceptibility to disease [18], results in less number of seeds set and reduces crops yield [19]. In soil as well as plants, $\mathrm{P}$ combines with $\mathrm{Zn}$ form phosphate complexes, which prevent absorption of $\mathrm{P}$ and movement of $\mathrm{P}$ in the plant. The current study was conducted to determine the effect of nitrogen and phosphorus in combination with $\mathrm{Zn}$ on maize yield and yield components.

Materials and methods

Experimental site, design and treatments

The experiment was conducted at University of Agriculture Peshawar,
Pakistan. It is located at $34^{\circ} \mathrm{N}$ and $71.3^{\circ}$

$\mathrm{E}$ at 350 meter above sea level. Daily maximum mean temperature ranges from 40 to $44{ }^{\circ} \mathrm{C}$ summer, while winter minimum temperature ranges from 4 to 5 ${ }^{\circ} \mathrm{C}$ [20]. Annual rainfall ranges from 450 to $750 \mathrm{~mm}$ with more than $60 \%$ rainfall occur in July and August [20]. Experimental plots were established in June 2013 at Agronomy Research Farms, University of Agriculture Peshawar Pakistan. Maize hybrid- 3305 was planted on the established plots on $14^{\text {th }}$ June, 2013 and harvested on 10th October 2013. Maize was planted on the same plots on $14^{\text {th }}$ June, 2014 and harvested in October 2014. Cultural practices, such is weeding, earthing up and thinning was done, canal water was the source of irrigation. Experiment was conducted according to randomized complete block (RCB) design having three replications. Three nitrogen levels $(150,200$ and $250 \mathrm{~kg} \mathrm{~N}$ $\left.\mathrm{ha}^{-1}\right)$, three phosphorus levels $(75,125$ and $175 \mathrm{~kg} \mathrm{P} \mathrm{ha}^{-1}$ ) and three zinc levels (5, 10 and $15 \mathrm{~kg} \mathrm{Zn} \mathrm{ha}^{-1}$ ) along with control were applied to maize. A plot size of $3 \mathrm{~m} \mathrm{x} 3.75 \mathrm{~m}$ having 5 rows 3 meter long, $75 \mathrm{~cm}$ apart was used. A plant to plant distance of $25 \mathrm{~cm}$ was maintained by thinning. Nitrogen was applied in three splits: 1st at time of sowing, 2nd at V5 (five leaf stage) and 3rd at VT stage, while full doses of $\mathrm{P}$ and $\mathrm{Zn}$ were applied at sowing to maize hybrid 3305 each year. Faba bean was planted each year after harvest of maize with no N, P or Zn application. The metrological data was obtained from the regional centre (Peshawar) of Pakistan Metrological Department (Figure 1). 


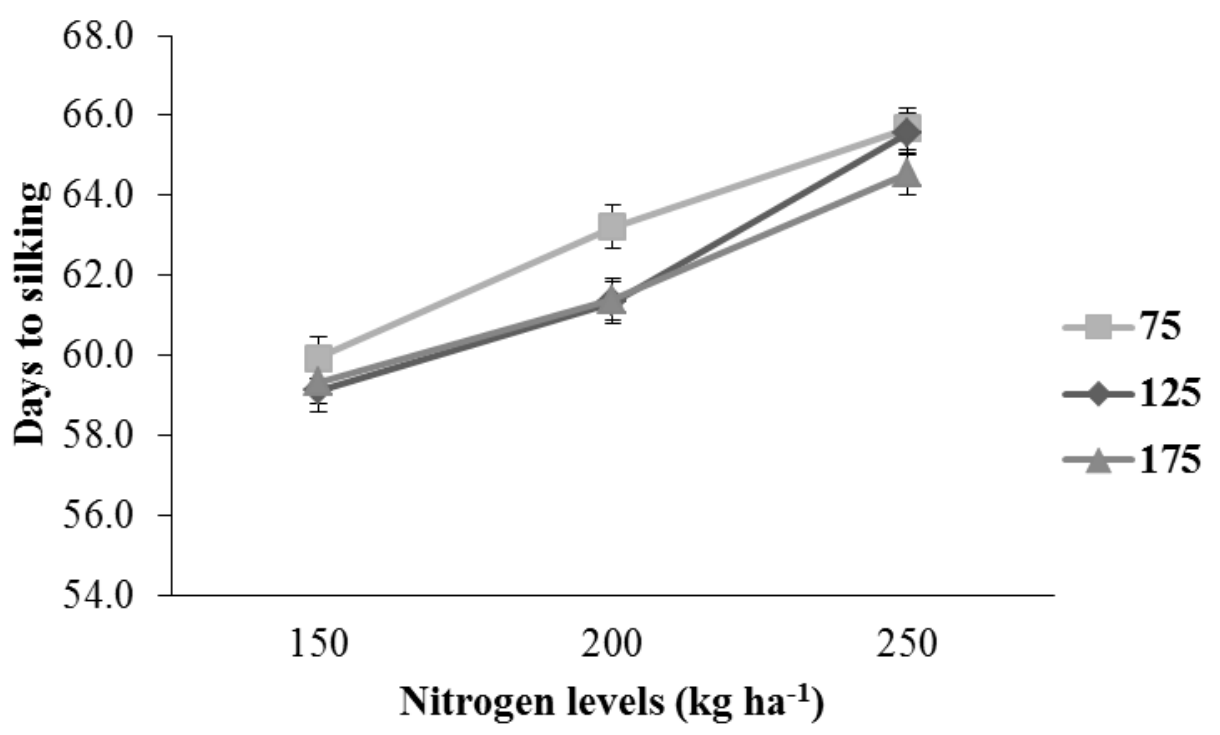

Figure 1. Days to silking of maize as affected by $\mathbf{N} x \mathbf{P}$ interaction.

\section{Soil Analysis}

A composite soil sample was taken from 0$30 \mathrm{~cm}$ depth before the start of the experiment and was analysed for $\mathrm{N}, \mathrm{P}$ and $\mathrm{Zn}$ content and other physical properties. Sampling from each experimental unit was done after each crop harvest and was analysed for different traits studied in the research. The soil was silty clay loam having $31.23 \%$ clay, $51.5 \%$ low $\mathrm{P}, \mathrm{N}$ and $\mathrm{Zn}$ content silt, $17.23 \%$ sand and low in $\mathrm{N}$ (0.04\%), P (1.15 mg kg-1) and $\mathrm{Zn}(0.7 \mathrm{mg}$ $\left.\mathrm{kg}^{-1}\right)$.

\section{Results and discussion Days to silking}

Statistical analysis of the data revealed that year $(\mathrm{Y})$, nitrogen $(\mathrm{N})$, phosphorus $(\mathrm{P})$, zinc $(\mathrm{Zn})$, control vs fertilizer and $\mathrm{N} \times \mathrm{P}$ interaction significantly affected days to silking (DS) of maize (Table 1). More DS (60.2) were recorded in 2014 compared with 2013. Generally higher DS (62) was observed for plots that received fertilizer compared with control. Mean values for $\mathrm{N}$ revealed that DS increased with each increment of $\mathrm{N}$ and maximum DS (65.3) were recorded at $250 \mathrm{~kg} \mathrm{~N} \mathrm{ha}{ }^{-1}$. Similar increases in DS were noted with each increment of $\mathrm{Zn}$ up to $15 \mathrm{~kg} \mathrm{Zn} \mathrm{ha}{ }^{-1}$. DS were higher (62.9) in plots where $\mathrm{P}$ was applied at the rate of $75 \mathrm{~kg} \mathrm{ha}^{-1}$, whereas higher level of $\mathrm{P}$ significantly reduced DS. Increase in DS was also noted with each increment of $\mathrm{Zn}$ up to $15 \mathrm{~kg} \mathrm{Zn} \mathrm{ha}^{-1}$ which resulted 63.1 days to silking. $\mathrm{N} \times \mathrm{P}$ interaction indicated that more days to silking were taken with $250 \mathrm{~kg} \mathrm{~N}$ and $75 \mathrm{~kg}$ $\mathrm{P} \mathrm{ha}^{-1}$. DS were delayed with each increment of $\mathrm{N}$ at all levels of $\mathrm{P}$ (Figure 1). Delay in DS due to increase in $\mathrm{N}$ level may be due to the fact that $\mathrm{N}$ enhances vegetative growth thus delaying the development of reproductive parts. Our results are in line with Dawadi and Shah [21] who reported that $\mathrm{N}$ delayed DS. Decrease in DS at higher level of $\mathrm{P}$ may be due to the fact that $\mathrm{P}$ is involved in root growth and the nutrients are efficiently utilized and the crop accelerates its growth. These results are in line with Amanullah et al. [22] who concluded that $\mathrm{P}$ application accelerate DS of maize. Zinc also delayed DS, which may be due to the fact that $\mathrm{Zn}$ control various physiological processes during vegetative growth and thus extended the vegetative growth. These results contradict with Asif et al. [23], who reported earlier DS with addition of zinc. 
Table 1. Days to silking of maize as affected by year, nitrogen, phosphorus and zinc levels

\begin{tabular}{|c|c|c|c|}
\hline \multirow[t]{2}{*}{ Nitrogen $\left(\mathrm{kg} \mathrm{ha}^{-1}\right)$} & \multicolumn{2}{|c|}{ Year } & \multirow[t]{2}{*}{ Mean } \\
\hline & 2013 & 2014 & \\
\hline 150 & 58.9 & 60.0 & $59.5 \mathrm{c}$ \\
\hline 200 & 61.3 & 62.7 & $62.0 \mathrm{~b}$ \\
\hline 250 & 64.9 & 65.6 & $65.3 \mathrm{a}$ \\
\hline \multicolumn{4}{|c|}{ Phosphorus (kg ha-1) } \\
\hline 75 & 62.7 & 63.1 & $62.9 \mathrm{a}$ \\
\hline 125 & 61.2 & 62.8 & $62.0 \mathrm{~b}$ \\
\hline 175 & 61.1 & 62.4 & $61.8 \mathrm{c}$ \\
\hline \multicolumn{4}{|l|}{ Zinc (kg ha $\left.{ }^{-1}\right)$} \\
\hline 5 & 60.9 & 62.1 & $61.5 \mathrm{c}$ \\
\hline 10 & 61.6 & 62.6 & $62.1 \mathrm{~b}$ \\
\hline 15 & 62.6 & 63.7 & $63.1 \mathrm{a}$ \\
\hline Control & 58 & 58 & $58 \mathrm{~b}$ \\
\hline Fertilizer & 62 & 63 & $62 \mathrm{a}$ \\
\hline Mean & $60.0 \mathrm{~b}$ & $60.2 \mathrm{a}$ & \\
\hline
\end{tabular}

$\operatorname{LSD}(0.05)$ for $\mathrm{N}=0.5, \operatorname{LSD}(0.05)$ for $\mathrm{P}=0.5, \operatorname{LSD}(0.05)$ for $\mathrm{Zn}=0.5$

Means followed by different letters in each category are significantly different at $5 \%$ level of probability using LSD test.

\section{Grains ear-1}

$\mathrm{Y}, \mathrm{N}, \mathrm{P}, \mathrm{Zn}$, control vs fertilizer and the $\mathrm{N} \mathrm{x}$ $\mathrm{P}$ and $\mathrm{N} \times \mathrm{Zn}$ interaction significantly affected grains ear $^{-1}(\mathrm{GE})$ of maize (Table 2). More GE (442.1) was recorded in the 2014 as compared to 2013. Generally higher GE (497) was recorded for plots that received fertilizer compared with control. Mean values for $\mathrm{N}$ revealed that $\mathrm{GE}$ increased with each increment of $\mathrm{N}$ and maximum GE (582.6) were recorded at 250 $\mathrm{kg} \mathrm{N} \mathrm{ha-1}$. Similar increases in GE were noted with each increment of $P$ up to $175 \mathrm{~kg}$ $\mathrm{p} \mathrm{ha}{ }^{-1}$. GE increased with each increment of $\mathrm{Zn}$ and higher GE (511.6) was recorded with $15 \mathrm{~kg} \mathrm{Zn} \mathrm{ha}{ }^{-1}$. N x P interaction indicated that higher GE was recorded with $250 \mathrm{~kg} \mathrm{~N}$ and $175 \mathrm{~kg} \mathrm{P} \mathrm{ha}^{-1}$. GE was increased with each increment of $\mathrm{N}$ at all levels of $\mathrm{P}$ (Figure 2). $\mathrm{N} \times \mathrm{Zn}$ interaction indicated that more GE was recorded at $250 \mathrm{~kg} \mathrm{~N}$ and 15 $\mathrm{kg} \mathrm{Zn} \mathrm{ha}{ }^{-1}$. GE increased with each increment of $\mathrm{N}$ at each level of $\mathrm{Zn}$ (Figure 3). Nitrogen play an important role in growth of pants and increasing nitrogen increased growth which produced more dry matter and ultimately resulting in higher GE. Our results are in line with Akhtar [24], who reported that $\mathrm{N}$ increase $\mathrm{GE}$. Increase in GE in case of higher level of $\mathrm{P}$ may be due to the fact that $\mathrm{P}$ is involved in many physiological processes and enhances the nutrient uptake of the plant by proliferating the roots and thus increasing total dry matter production which enhanced GE. These results are in line with Bereaz [25] who reported that GE increases with each increment of $\mathrm{P}$. Zinc also increased GE which may be due to the fact that $\mathrm{Zn}$ produces more fertile pollens which results in more seed sets. Moreover, zinc also play important role in pollen tube formation which resulted in fertilization of more number of eggs and lead to higher number of grains ear ${ }^{-1}$. These results are supported by the findings of Kenbaev and Sade [26], Gul et al. [27] and Harris et al. [28] who concluded that GE increases with each increment of $\mathrm{Zn}$. 
Table 2. Number of grains ear ${ }^{-1}$ of maize as affected by year, nitrogen, phosphorus and zinc levels

\begin{tabular}{|l|c|c|c|}
\hline \multirow{2}{*}{ Nitrogen (kg ha-1) } & \multicolumn{2}{|c|}{ Year } & \multirow{2}{*}{ Mean } \\
\cline { 2 - 4 } & $\mathbf{2 0 1 3}$ & $\mathbf{2 0 1 4}$ & $400.6 \mathrm{c}$ \\
\hline 150 & 377.1 & 424.0 & $508.7 \mathrm{~b}$ \\
\hline 200 & 487.9 & 529.5 & $582.6 \mathrm{a}$ \\
\hline Phosphorus (kg ha-1) & 560.9 & 604.3 & $469.1 \mathrm{c}$ \\
\hline 75 & 447.2 & 491.1 & $493.9 \mathrm{~b}$ \\
\hline 125 & 473.1 & 514.7 & $528.8 \mathrm{a}$ \\
\hline 175 & 505.6 & 551.9 & $481.4 \mathrm{c}$ \\
\hline Zinc (kg ha & \multicolumn{3}{|c|}{ ) } \\
\hline 5 & 459.3 & 503.6 & $498.8 \mathrm{~b}$ \\
\hline 10 & 477.2 & 520.5 & $511.6 \mathrm{a}$ \\
\hline 15 & 489.5 & 533.7 & $342 \mathrm{~b}$ \\
\hline Control & 318 & 365 & $497 \mathrm{a}$ \\
\hline Fertilizer & 475 & 519 & \\
\hline Mean & $396.7 \mathrm{~b}$ & $442.1 \mathrm{a}$ & \\
\hline
\end{tabular}

$\operatorname{LSD}(0.05)$ for $\mathrm{N}=4.96, \operatorname{LSD}(0.05)$ for $\mathrm{P}=4.96, \operatorname{LSD}(0.05)$ for $\mathrm{Zn}=4.96$

Means followed by different letters in each category are significantly different at $5 \%$ level of probability using LSD test.



Figure 2. Number of grains ear ${ }^{-1}$ of maize as affected by $\mathbf{N} x \mathrm{P}$ interaction 


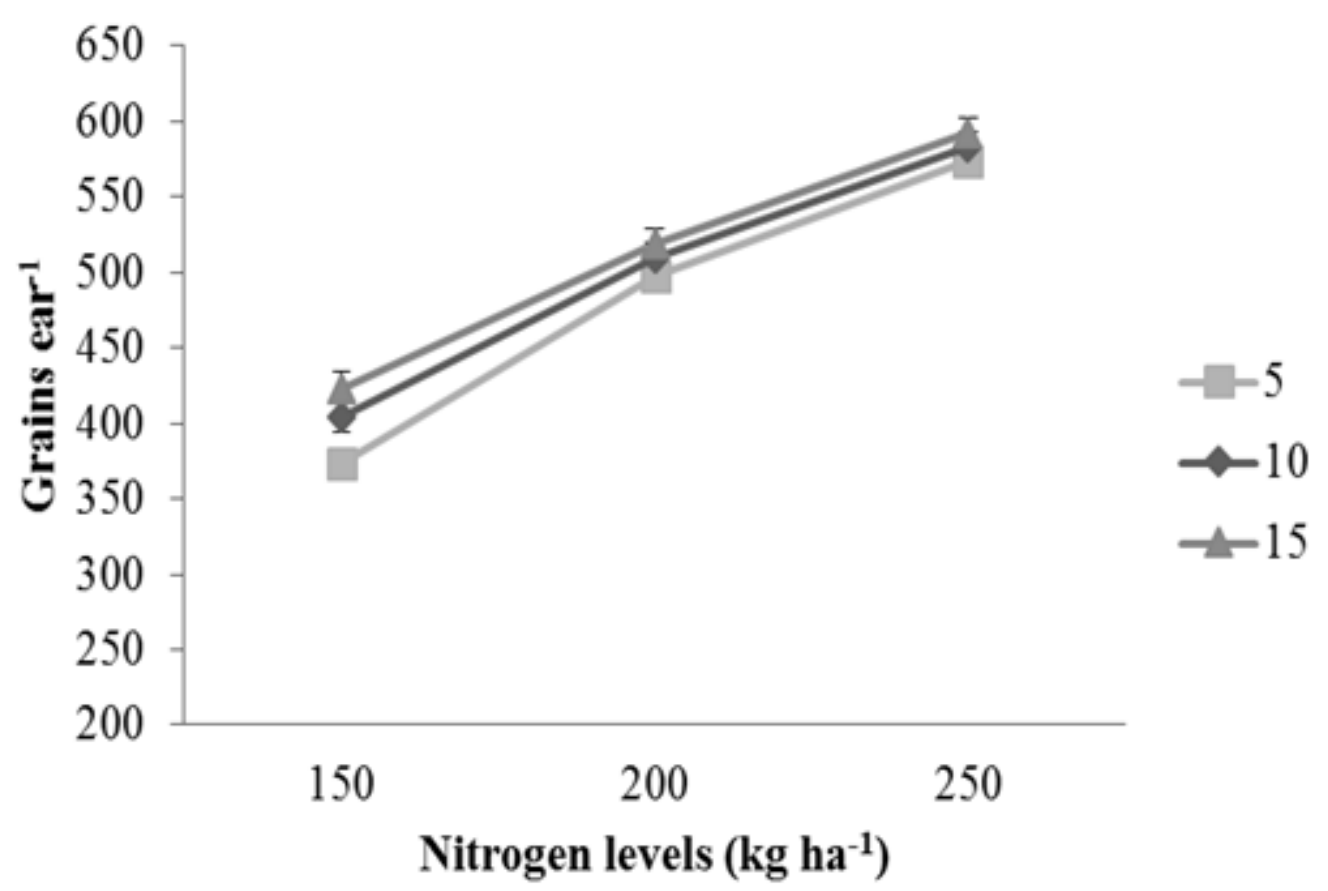

Figure 3. Number of grains ear ${ }^{-1}$ of maize as affected by $N \times$ Zn interaction

Thousand grains weight $(\mathrm{g})$

$\mathrm{Y}, \mathrm{N}, \mathrm{P}, \mathrm{Zn}$, control vs fertilizer and the $\mathrm{N} \mathrm{x}$ $\mathrm{P}$ interaction significantly affected thousand grains weight (TGW) of maize (Table 3). Heavier TGW (319.8 g) were recorded in the year 2014 as compared to 2013. Generally higher TGW (338 g) was recorded for plots that received fertilizer compared with control. Mean values for $\mathrm{N}$ revealed that TGW increased with each increment of $\mathrm{N}$ and maximum TGW (379.9 g) were recorded at $250 \mathrm{~kg} \mathrm{~N} \mathrm{ha}^{-1}$. Similar increase in TGW was noted with each increment of $P$ up to $175 \mathrm{~kg} \mathrm{Pha}^{-1}$.TGW was increased with each increment of $\mathrm{Zn}$ and higher TGW $(343.3 \mathrm{~g})$ was noted with $15 \mathrm{~kg} \mathrm{Zn} \mathrm{ha}^{-1}$. N x $\mathrm{P}$ interaction revealed that TGW was higher with $250 \mathrm{~kg} \mathrm{~N}$ and $175 \mathrm{~kg} \mathrm{P} \mathrm{ha}^{-1}$. TGW was increased each increment of $\mathrm{N}$ at all three levels of P (Figure 4). Increase in TGW in case of $\mathrm{N}$ might be due to the fact that nitrogen enhanced the rate of photosynthesis and more dry matter accumulation which resulted in heavier grains. Our results are in line with Alam and Jan [29] and Hussain et al. [30] who concluded that TGW increases with each increment of N. Similarly P levels also increased TGW which might be attributed to the $\mathrm{P}$ role as energy formation and constituent of the plant parts as well as its effect in increasing growth of the crop which resulted in more assimilates formation. These results are in agreement with Sahoo and Panda [31] who reported maximum grain weight with higher $P$ application. In case of $\mathrm{Zn}$ thousand grains weight increased due to the involvement of the $\mathrm{Zn}$ in enzyme activation, membrane integrity, chlorophyll formation, stomatal regulation and starch utilization at early stages, while enhanced accumulation of assimilate in the grains, which resulted in heavier grains. These results are supported by Harris et al. [28] and Karim et al. [32] who observed increase in TGW with each increment of $\mathrm{Zn}$. 
Table 3. Thousand grains weight (g) of maize as affected by year, nitrogen, phosphorus and zinc levels.

\begin{tabular}{|c|c|c|c|}
\hline \multirow[t]{2}{*}{ Nitrogen $\left(\mathrm{kg} \mathrm{ha}^{-1}\right)$} & \multicolumn{2}{|c|}{ Year } & \multirow[t]{2}{*}{ Mean } \\
\hline & 2013 & 2014 & \\
\hline 150 & 282.1 & 315.1 & $298.6 \mathrm{c}$ \\
\hline 200 & 320.1 & 351.2 & $335.7 \mathrm{~b}$ \\
\hline 250 & 365.2 & 394.6 & $379.9 \mathrm{a}$ \\
\hline \multicolumn{4}{|c|}{ Phosphorus (kg ha $\left.{ }^{-1}\right)$} \\
\hline 75 & 309.4 & 340.3 & $324.9 \mathrm{c}$ \\
\hline 125 & 321.0 & 353.3 & $337.2 \mathrm{~b}$ \\
\hline 175 & 337.0 & 367.3 & $352.2 \mathrm{a}$ \\
\hline \multicolumn{4}{|l|}{ Zinc $\left(\mathrm{kg} \mathrm{ha}^{-1}\right)$} \\
\hline 5 & 316.3 & 348.0 & $332.1 \mathrm{c}$ \\
\hline 10 & 323.3 & 354.3 & $338.8 \mathrm{~b}$ \\
\hline 15 & 327.9 & 358.6 & $343.3 \mathrm{a}$ \\
\hline Control & 253 & 286 & $269 \mathrm{~b}$ \\
\hline Fertilizer & 322 & 354 & $338 \mathrm{a}$ \\
\hline Mean & $287.6 \mathrm{~b}$ & $319.8 \mathrm{a}$ & \\
\hline
\end{tabular}

$\operatorname{LSD}(0.05)$ for $\mathrm{N}=2.6, \mathrm{LSD}(0.05)$ for $\mathrm{P}=2.6, \mathrm{LSD}(0.05)$ for $\mathrm{Zn}=2.6$

Means followed by different letters in each category are significantly different at $5 \%$ level of probability using LSD test

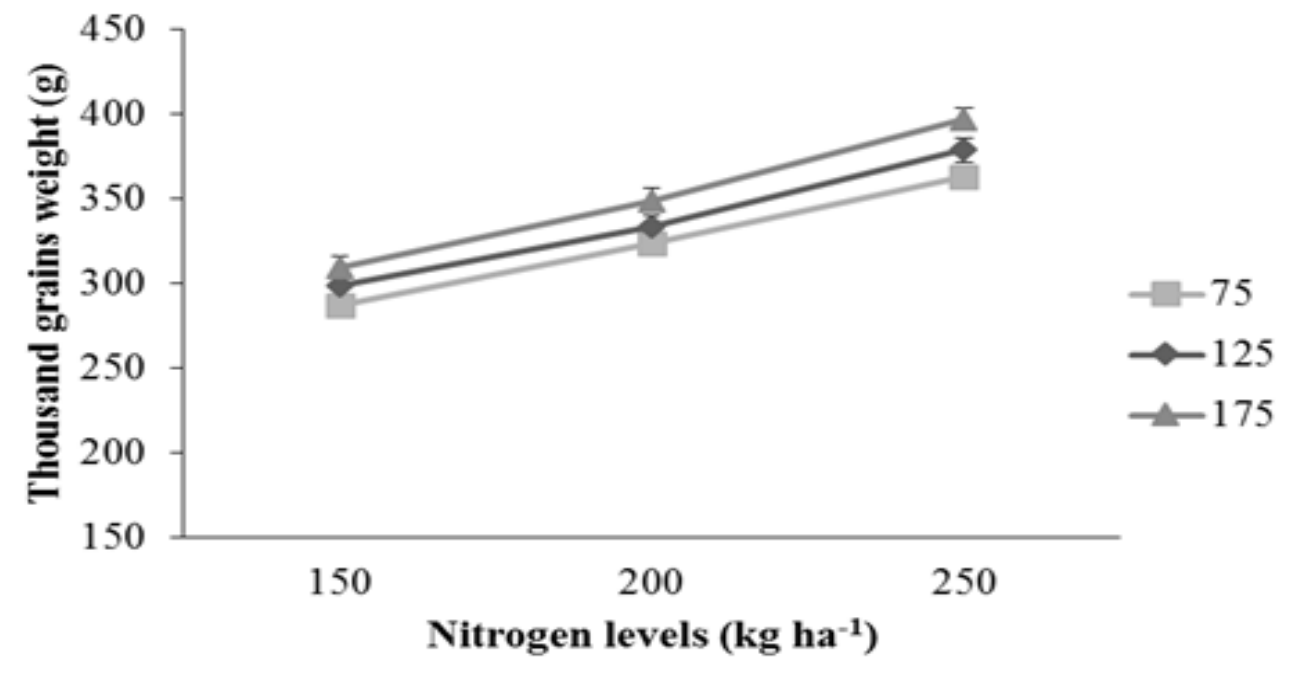

Figure 4. Thousand grains weight (g) of maize as affected by $N \times P$ interaction

\section{Soil P ( mg kg $\left.^{-1}\right)$}

Soil $\mathrm{P}$ content was significantly affected by years ( $\mathrm{S}), \mathrm{N}, \mathrm{P}, \mathrm{Zn}$, control vs fertilizer, $\mathrm{N} x$ $\mathrm{P} \times \mathrm{Zn}, \mathrm{S} \times \mathrm{N}, \mathrm{S} \times \mathrm{P}, \mathrm{S} \times \mathrm{Zn}$ and $\mathrm{S} \times$ Control vs fertilizer interactions (Table 4). Mean values of the data indicated that soil $\mathrm{P}$ was higher in the first season after maize harvest and lower soil $\mathrm{P}$ was recorded in the $2^{\text {nd }}$ season. Soil $\mathrm{P}$ of unfertilized plots was lower as compared with fertilized plots. Soil $\mathrm{P}$ was increased with each increment of $\mathrm{N}$ and higher soil $\mathrm{P}$ was recorded with application of $250 \mathrm{~kg} \mathrm{~N}$ ha $^{-1}$ which was statistically at par with $\mathrm{N}$ applied at the rate of $200 \mathrm{~kg} \mathrm{ha}^{-1}$. Soil $\mathrm{P}$ was also increased with each increment of $\mathrm{P}$ and higher soil $\mathrm{P}$ 
was recorded with $175 \mathrm{~kg} \mathrm{P} \mathrm{ha}^{-1}$. Zn decreased soil $\mathrm{P}$ with each increment of $\mathrm{Zn}$ and higher soil $\mathrm{P}$ was found with application of $5 \mathrm{~kg} \mathrm{Zn} \mathrm{ha}{ }^{-1}$. N x $\mathrm{P} \times \mathrm{Zn}$ interaction revealed that higher $\mathrm{P}$ was recorded with application of $15 \mathrm{~kg} \mathrm{Zn,} 175 \mathrm{~kg} \mathrm{P}$ and 200 $\mathrm{kg} \mathrm{N} \mathrm{ha}{ }^{-1}$. Soil $\mathrm{P}$ was decreased with increasing $\mathrm{Zn}$ level at 75 and $125 \mathrm{~kg} \mathrm{P}$ irrespective of $\mathrm{N}$, however soil $\mathrm{P}$ increased with increase in $\mathrm{P}, \mathrm{P}$ content were increased with increase in $\mathrm{Zn}$ level at $200 \mathrm{~kg} \mathrm{~N}^{-1}$ (Figure 5). $\mathrm{S} \times \mathrm{N}$ interaction indicated that soil $\mathrm{P}$ was higher with $200 \mathrm{~kg} \mathrm{~N} \mathrm{ha}^{-1}$ in first season after maize and decreased in $2^{\text {nd }}$ season. S x $\mathrm{P}$ interaction revealed that soil $\mathrm{P}$ was higher with $175 \mathrm{~kg} \mathrm{P} \mathrm{ha}^{-1}$ in the first season where as it was decreased after $2^{\text {nd }}$ season. $\mathrm{S} \times \mathrm{Zn}$ interaction revealed soil $\mathrm{P}$ was higher with $5 \mathrm{~kg} \mathrm{Zn} \mathrm{ha}^{-1}$ in the first season, however increasing $\mathrm{Zn}$ decreased the soil $\mathrm{P}$ in both years. $\mathrm{S} x$ control vs fertilizer interaction revealed that higher soil $\mathrm{P}$ was recorded in the fertilized plots in first season, whereas the soil P decreased in each season in unfertilized plots. Increase in soil $\mathrm{P}$ due to nitrogen application might be attributed to the property of $\mathrm{N}$ to decrease the $\mathrm{P}$ uptake which resulted in low use of $\mathrm{P}$. Contradictory results were found by Shehu et al. [33] who reported higher P uptake with increasing $\mathrm{N}$. In case of $\mathrm{P}$ fertilizer soil $\mathrm{P}$ content increased, which might be attributed to more accumulation of $\mathrm{P}$ in soil and the crop take some part of it and the rest remain in soil. Similar results were reported earlier by Shehu et al. [33]. After the first experiment faba bean was grown on the same established plots in rabi season which is a $\mathrm{P}$ loving crop, due to which soil $\mathrm{P}$ decreased in the $2^{\text {nd }}$ year as compared to the first year. The increase in $\mathrm{Zn}$ content decreased the soil $\mathrm{P}$ content which might be attributed to the $\mathrm{Zn}$ property that $\mathrm{P}$ uptake was reduced with increasing $\mathrm{Zn}$ which resulted in more $\mathrm{P}$ accumulation in soil. These results are in contrast with those of Abbas et al. [34]. The increase in $\mathrm{N}$ content with the application of $\mathrm{N}$ might be due to the fact that all applied nitrogen was not utilized by the crop, remained in the soil and thus increased the soil $\mathrm{N}$ content. These results are in line with Sebilo et al. [35] who reported that increasing $\mathrm{N}$ dose also increased soil $\mathrm{N}$.

Table 4. Soil Phosphorus (mg kg-1) as affected by year, nitrogen, phosphorus and zinc levels

\begin{tabular}{|c|c|c|c|}
\hline \multirow[t]{2}{*}{ Nitrogen $\left(\mathrm{kg} \mathrm{ha}^{-1}\right)$} & \multicolumn{2}{|c|}{ Year } & \multirow[t]{2}{*}{ Mean } \\
\hline & 2013 & 2014 & \\
\hline 150 & 2.89 & 2.66 & $2.77 \mathrm{~b}$ \\
\hline 200 & 3.11 & 2.91 & $3.01 \mathrm{a}$ \\
\hline 250 & 2.90 & 2.92 & $2.91 \mathrm{a}$ \\
\hline \multicolumn{4}{|c|}{ Phosphorus (kg ha $\left.{ }^{-1}\right)$} \\
\hline 75 & 2.89 & 2.74 & $2.8 \mathrm{~b}$ \\
\hline 125 & 2.88 & 2.82 & $2.85 \mathrm{ab}$ \\
\hline 175 & 3.13 & 2.93 & $3.03 \mathrm{a}$ \\
\hline \multicolumn{4}{|l|}{ Zinc $\left(\mathrm{kg} \mathrm{ha}^{-1}\right)$} \\
\hline 5 & 3.22 & 3.14 & $3.18 \mathrm{a}$ \\
\hline 10 & 2.84 & 2.79 & $2.81 \mathrm{~b}$ \\
\hline 15 & 2.83 & 2.56 & $2.69 \mathrm{~b}$ \\
\hline Control & 1.63 & 0.30 & $0.96 \mathrm{~b}$ \\
\hline Fertilizer & 2.97 & 2.83 & $2.9 \mathrm{a}$ \\
\hline Mean & $2.30 \mathrm{a}$ & $1.57 \mathrm{~b}$ & \\
\hline
\end{tabular}

$\operatorname{LSD}(0.05)$ for Years $=0.15$, Nitrogen $=0.13$, Phosphorus $=0.13$, Zinc $=0.13$.

Means followed by different letters in each category are significantly different at $5 \%$ level of probability using LSD test. 


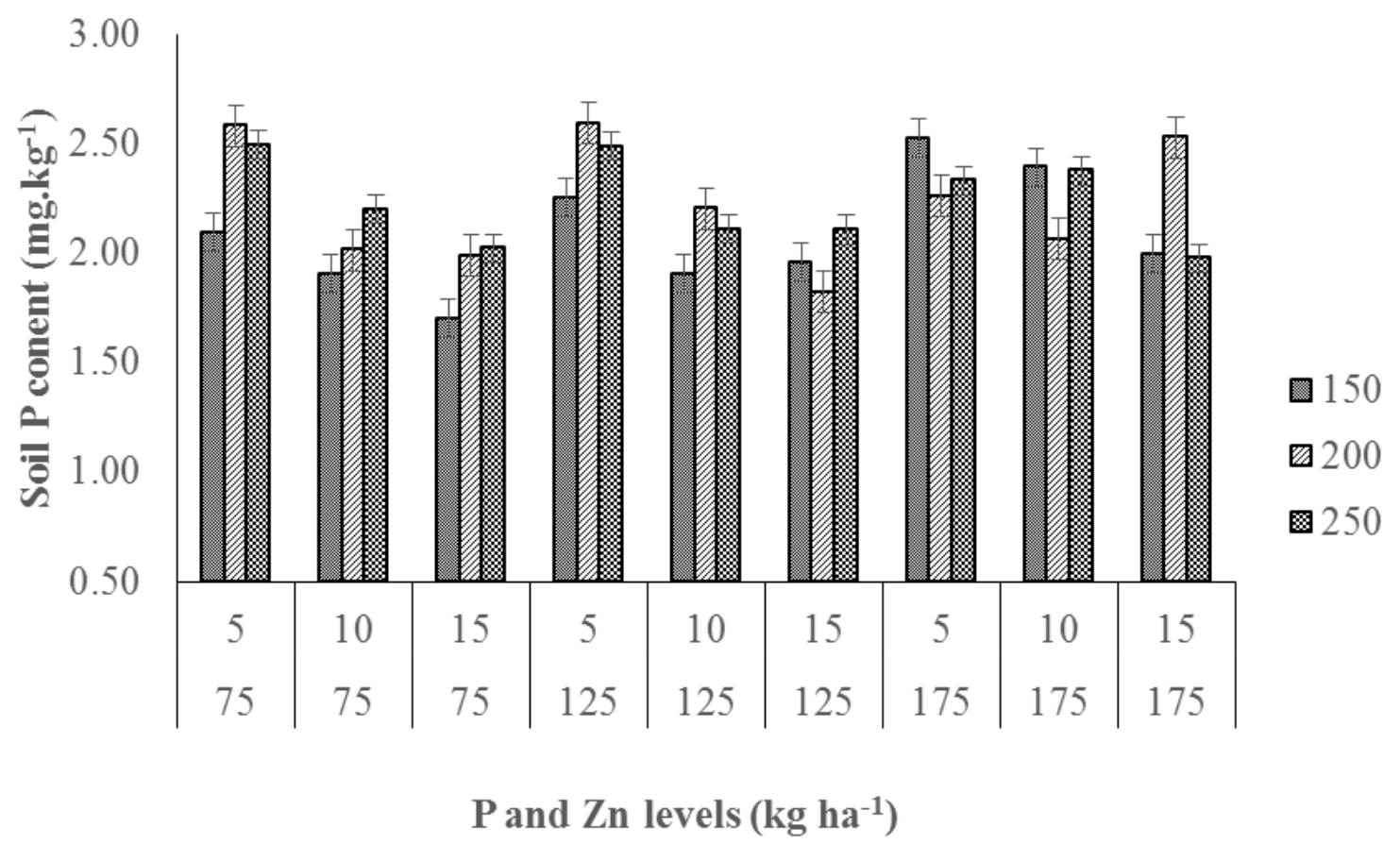

Figure 5. Soil $P$ content as affected by $N \times P \times Z n$ interaction. Standard error $=(T)$

Soil Zn (mg kg-1)

Soil Zn was significantly affected by $\mathrm{S}, \mathrm{P}$, $\mathrm{Zn}$, control vs fertilizer, $\mathrm{N} \times \mathrm{P}, \mathrm{N} \times \mathrm{P} \times \mathrm{Zn}$ and $\mathrm{S} x$ Control vs fertilizer (Table 5). Mean values of the data indicated that soil $\mathrm{Zn}$ was higher in the $3^{\text {rd }}$ season. The soil $\mathrm{Zn}$ of unfertilized plots was lower as compared with fertilized plots. Soil $\mathrm{Zn}$ was increased with each increment of $\mathrm{P}$ and higher soil $\mathrm{Zn}$ was recorded with $175 \mathrm{~kg} \mathrm{Pha}^{-1}$. Applied $\mathrm{Zn}$ also increased the soil $\mathrm{Zn}$ with each increment of $\mathrm{Zn}$ and higher soil $\mathrm{Zn}$ was recorded with application of $15 \mathrm{~kg} \mathrm{Zn} \mathrm{ha}^{-1}$. $\mathrm{N} \times \mathrm{P}$ interaction indicated that higher soil $\mathrm{Zn}$ was recorded with addition of $250 \mathrm{~kg} \mathrm{~N}$ and $175 \mathrm{~kg} \mathrm{P} \mathrm{ha}^{-1}$, the soil $\mathrm{Zn}$ increased with increasing P level and at 250 and $150 \mathrm{~kg} \mathrm{~N}$ $\mathrm{ha}^{-1}$, while the soil $\mathrm{Zn}$ decreased with increasing $\mathrm{P}$ at $200 \mathrm{~kg} \mathrm{~N} \mathrm{ha}^{-1}$ (Figure .6). $\mathrm{N}$ $\mathrm{x} \mathrm{P} \times \mathrm{Zn}$ interactions indicated that higher soil $\mathrm{Zn}$ was recorded with $150 \mathrm{~kg} \mathrm{~N}, 15 \mathrm{~kg}$ $\mathrm{Zn}$ and $175 \mathrm{~kg} \mathrm{P}^{-1}$, soil $\mathrm{Zn}$ increased with increasing $\mathrm{Zn}$ and $\mathrm{P}$ at all levels of $\mathrm{N}$, however the increase was higher at $150 \mathrm{~kg} \mathrm{~N}$ $\mathrm{ha}^{-1}$ (Figure 7). S x control vs fertilizer interaction indicated that $\mathrm{Zn}$ content of the soil was higher in fertilized plots in $3^{\text {rd }}$ season after maize and decreased each season in unfertilized plots. Higher soil $\mathrm{Zn}$ in case of higher $\mathrm{Zn}$ application might be the reason that as micronutrient $\mathrm{Zn}$ is required in low quantity by crop, thus crop utilizes some the applied $\mathrm{Zn}$ and the rest is leftover in the soil. Similar results were reported by Asad and Rafique [36] and Khan et al. [37]. 
Table 5. Soil $\mathrm{Zn}\left(\mathrm{mg} \mathrm{kg}^{-1}\right)$ after harvest of maize as affected by year, nitrogen, phosphorus and zinc

\begin{tabular}{|c|c|c|c|}
\hline \multirow{2}{*}{ Nitrogen $\left(\mathrm{kg} \mathrm{ha}^{-1}\right)$} & \multicolumn{2}{|c|}{ Year } & \multirow[t]{2}{*}{ Mean } \\
\hline & 2014 & 2015 & \\
\hline 150 & 6.22 & 6.91 & 6.56 \\
\hline 200 & 6.43 & 6.65 & 6.54 \\
\hline 250 & 6.46 & 6.81 & 6.63 \\
\hline \multicolumn{4}{|c|}{ Phosphorus (kg ha-1) } \\
\hline 75 & 6.22 & 6.69 & $6.56 \mathrm{~b}$ \\
\hline 125 & 6.32 & 6.88 & $6.66 \mathrm{~b}$ \\
\hline 175 & 6.57 & 6.79 & $6.68 \mathrm{a}$ \\
\hline \multicolumn{4}{|l|}{ Zinc $\left(\mathrm{kg} \mathrm{ha}^{-1}\right)$} \\
\hline 5 & 6.23 & 6.58 & $6.40 \mathrm{~b}$ \\
\hline 10 & 6.18 & 6.83 & $6.50 \mathrm{~b}$ \\
\hline 15 & 6.70 & 6.95 & $6.82 \mathrm{a}$ \\
\hline Control & 2.93 & 4.40 & $3.68 \mathrm{~b}$ \\
\hline Fertilizer & 6.37 & 6.79 & $6.58 \mathrm{a}$ \\
\hline Mean & $4.65 \mathrm{~b}$ & $5.59 \mathrm{a}$ & \\
\hline
\end{tabular}

$\operatorname{LSD}(0.05)$ for Years $=0.78$, Phosphorus $=0.12$, Zinc $=0.12$

Mean values followed by different letters in each category are significantly different at $5 \%$ level of probability using LSD test.

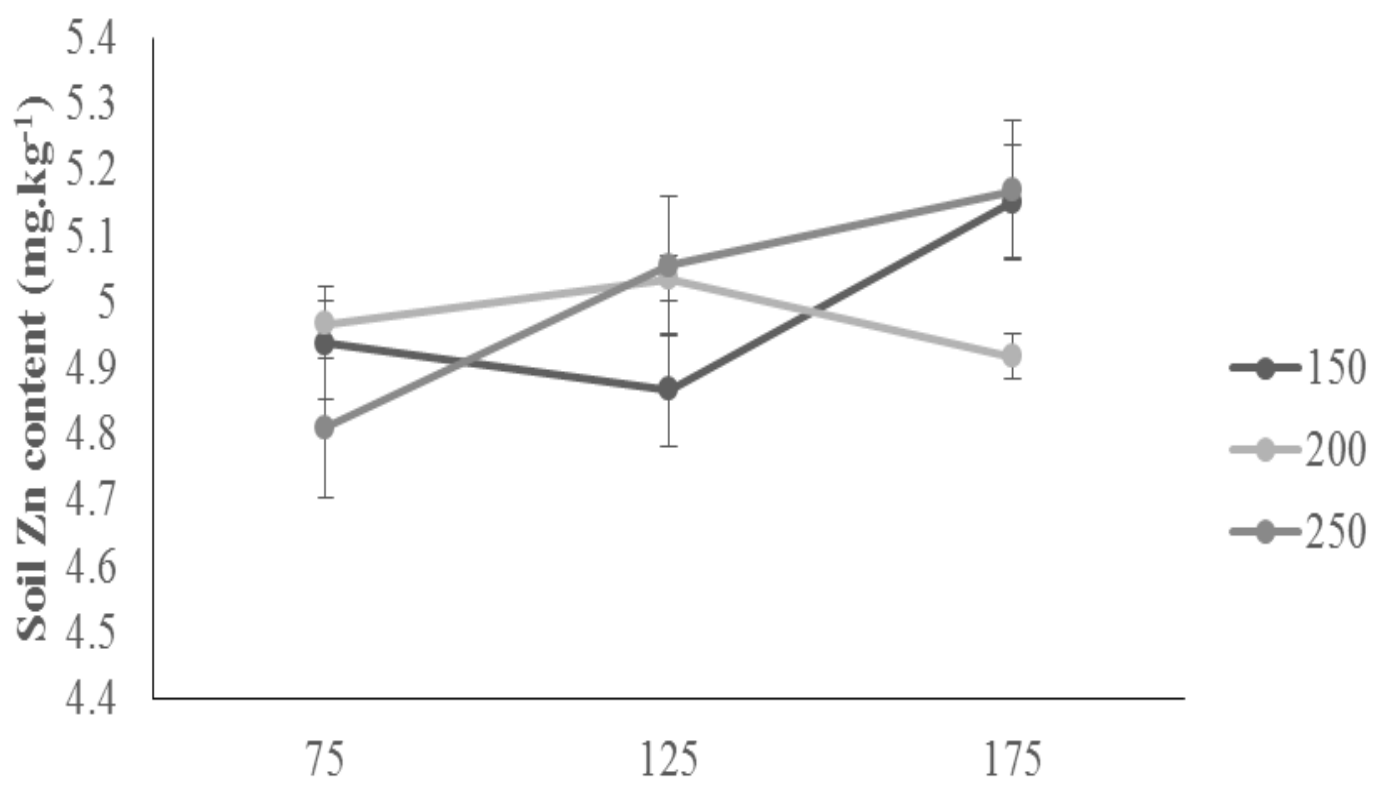

Plevel $\left(\mathrm{kg} \mathrm{ha}^{-1}\right)$

Figure 6. Soil Zn content as affected by $\mathbf{N} x \mathrm{P}$ interaction. 


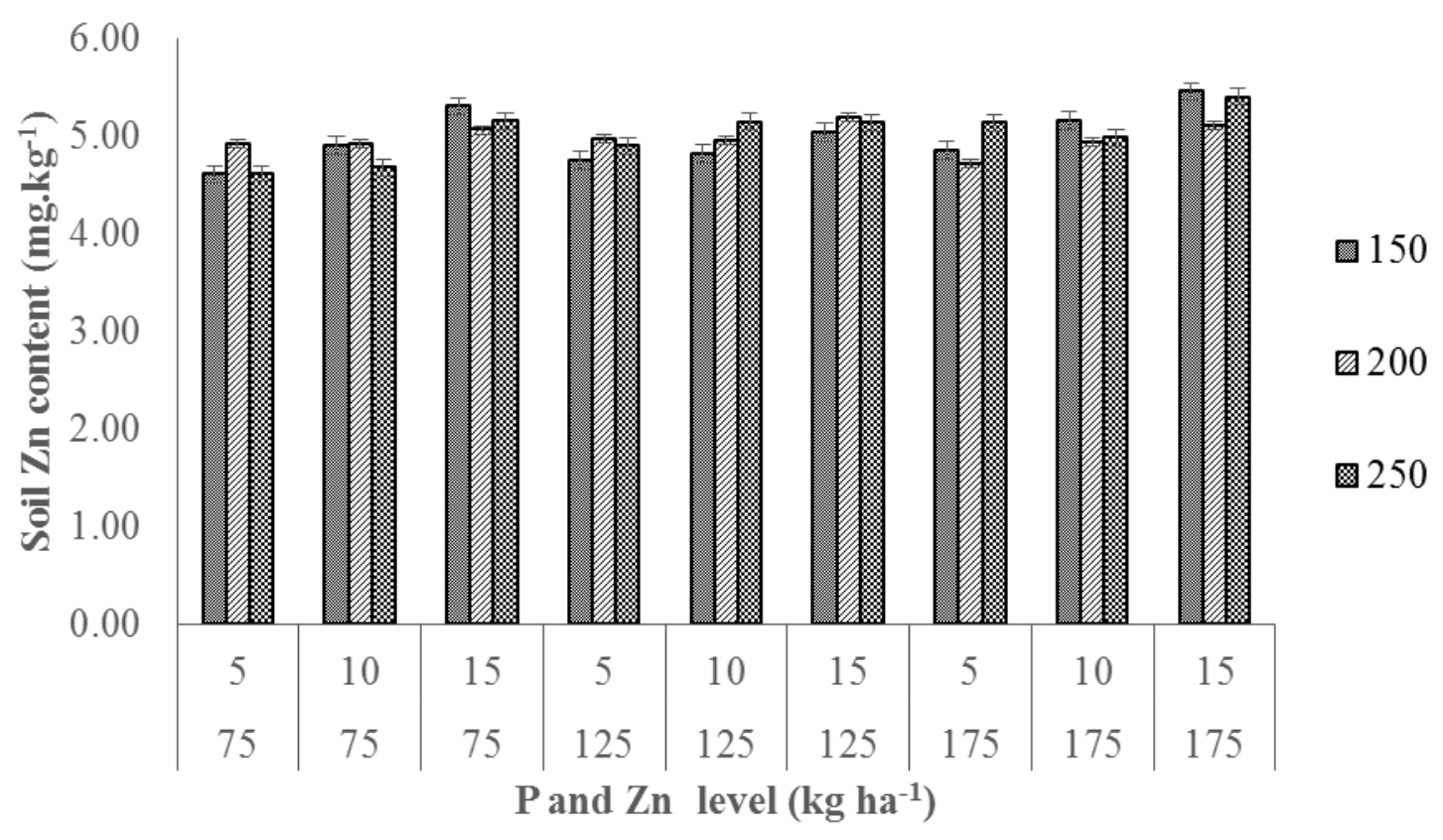

Figure 7. Soil $\mathrm{Zn}$ content as affected by $N \times P \times Z n$ interaction ( $T^{=}=$Standard error).

\section{Conclusion}

$\mathrm{N}, \mathrm{P}$ and $\mathrm{Zn}$ applied at the rate of 250,175 and $15 \mathrm{~kg} \mathrm{ha}^{-1}$ respectively increased soil fertility and productivity of hybrid maize 3305.

\section{Authors' contributions}

Conceived and designed the experiments: SK Khalil, Performed the experiments: Imranuddin. Analyzed the data: SK Khalil, Contributed reagents/ materials/ analysis tools and wrote the paper: Imranuddin

\section{Acknowledgement}

Higher Education Commission Islamabad is acknowledged for providing financial support for this project and Dr. Ahmad Khan, Assistant Professor for assistance in statistical analysis.

\section{References}

1. Akmal, MH, Rehman, Farhatuallah, Asim M \& Akbar H (2010). Response of maize varieties to nitrogen application for leaf area profile, crop growth and yield components. Pak J Bot 42: 1941-1947.

2. Khaliq $\mathrm{T}$, Mahmood $\mathrm{T} \&$ Masood A (2004). Effectiveness of farmyard manure, poultry manure and nitrogen for corn (Zea mays L.) productivity. Inter J Agri Bio 2: 260-263.

3. Enyisi S, Uman VJ, Whong CMZ, Abdullahi IO \& Alabi O (2014). Chemical and nutritional value of maize and maize products obtained from selected markets in Kadnna state, Nigeria. Afr J food Sci Tech 5(4): 100104.

4. Khattak MK, Khan MJ, Mughal AQ, Bukhari SB \& Jan MT (2004). Influence of various tillage practices on yield of wheat-maize under clay loam soil condition. Sarhad J Agric 20: 429435.

5. Orloff S, Wright S \& Ottman M (2012) .Nitrogen management impacts on wheat yield and protein. In: Proceedings, California Alfalfa \& Grains Symposium, Sacramento, CA, December 11-12.

6. Paszkiewicz S \& Butzen S (2010). Corn hybrid response to plant population. Crop Insights 17: 1-4 
7. Sharif M, Arif M, Burni T, Khan F, Jan B \& Khan I (2014). Growth and phosphorus uptake of sorghum plants in salt affected soil as affected by organic materials composted with rock phosphate. Pak. J. Bot 46(1): 173-180.

8. Wahid F, Muhammad S, Khan MA, Ali A, Khattak AM \& Saljoqi AR (2015). Wheat yield and phosphorus uptake as affected by rock phosphate added with different organic fertilizers. Ciência e TécnicaVitivinícola J 30(3): 90-100.

9. Havlin JL, Beaton JD, Tisdale SL \& Nelson WL (2005). Soil fertility and fertilizers (7thed.) Pearson Education Limited, USA.

10. Shenoy VV \& Kalagudi GM (2005). Enhancing plant phosphorus use efficiency for sustainable cropping. Biotech. Adv 23: 501-513.

11. Singaram P \& KotharIdaraman GV (1994). Studies on residual, direct and cumulative effect of phosphorous source on the availability, content and uptake of phosphorus and yield of maize. Madras Agri J 81: 425-429.

12. Zayed BA, Salem AKM \& Sharkawy HME (2011). Effect of different micronutrient treatments on rice (Oryzasativa L.) growth and yield under saline soil conditions. World J Agric Sci 7(2): 179-18.

13. Alloway B (2004). Zinc in soils and crop nutrition. Areas of the world with zinc deficiency problems. Available at: http://www.zinc-crops.org/Crops/Alloway-all.php

14. Kobraee S, Mohamadi NN, Sharifabad HH, Kajori FD \& Delkhosh B (2011). Influence of micronutrient fertilizer on soybean nutrient composition. Indian J Sci Technol 4(7): 763-769.

15. Graham RD, Welch RM \& Bouis HE (2000). Addressing micronutrient nutrition through enhancing the nutritional quality of staple foods. Advances in Agronomy 70: 77-161.

16. Sawan ZM, Mahmoud MH \& El-Guibali $\mathrm{AH}$ (2008). Influence of potassium fertilization and foliar application of zinc and phosphorus on growth, yield components, yield and fiber properties of Egyptian cotton (Gossypium barbadense L.). J Plant Ecol 1: 259270.

17. Yosefi K, Galavi M, Ramrodi M \& Mousavi SR (2011). Effect of biophosphate and chemical phosphorus fertilizer accompanied with micronutrient foliar application on growth, yield and yield components of maize (Single Cross 704). Aust J Crop Sci 5(2): 175-180.

18. Ghasemian V, Ghalavand A, Zadeh AS \& Pirzad A (2010). The effect of iron, zinc and manganese on quality and quantity of soybean seed. J. Phytol 2(11): 73-79.

19. Ziaeyan AH \& Rajaie M (2009). Combined effect of zinc and boron on yield and nutrients accumulation in corn. Int J Plant Prod 3(3): 35-44.

20. Google Inc.2015. Google Earth. Version:5. 2.1. 1588. Europa Technologies https://www.europa.uk.com/google/

21. Dawadi R \& Sah SK (2012). Growth and yield of hybrid maize (Zea mays L.) in relation to planting density and nitrogen levels during winter season in Nepal. Tropical. Agric. Res 23 (3): 218- 227.

22. Amanullah M, Zakirullah \& Khalil SK (2010). Timing and rate of phosphorus application influence maize phenology, yield and profitability in Northwest Pakistan. Int J Plant Prod 4(4): 281292.

23. Asif M, Saleem F, Anjum SA, Wahid M A \& Bilal MF (2013). Effect of nitrogen and zinc sulphate on growth 
and yield of maize. J Agri Res 51(4): 455-464.

24. Akhtar MM (2001). Effect of varying levels of nitrogen on growth and yield performance of two new cultivars. M.sc (Hons) thesis, Dept of agronomy, Uni of agri. Faisalabad (Pakistan). pp 84-86.

25. Bereaz K (2000). Grain yield and quality of winter wheat varieties as affected by different nutrient supply. Inter. Plnt. Nutri. Collo. Han. Germany 342-343.

26. Kenbaev B \& Sade B (2002). Response of field-grown barley cultivars grown on zinc deficient soil to zinc application. Comm. Soil Sci. Plant Anal 33: 533-544.

27. Gul H, Said A, Saeed B, Ahmad I \& Ali K (2011). Response of yield and yield components of wheat towards foliar spray of nitrogen, potassium and zinc. $J$ Agric Biol Sci 6(2).onlineat:http://www.arpnjournals.c om/jabs/research_papers/rp_2011/jabs_ 041 1_265.pdf

28. Harris A, Rashid G, Miraj G, Asif M \& Shah H (2007). On-farm seed priming with zinc sulphate solution. A costeffective way to increase the maize yield of resources of poor farmers. Field crop Res 110: 119-127.

29. Alam AK \& Jan A (2003). Effect of nitrogen and seed size on yield and yield components of maize crop. J Agri Soc Sci 1(12): 6-14

30. Hossain MA, Hamid A \& Nasreen S (2007). Effect of nitrogen and phosphorus fertilizer on N/P uptake and yield performance of groundnut. $J$ Agric Res 45(2): 119- 127.

31. Sahoo SC \& Panda M (2001). Effect of Phosphorus and detassseling on yield of baby corn. The Ind. J. Agric. Scie 71: 21-22.

32. Karim MR, Zhang YQ, Zhao RR, Chen XP, Zhang FS \& Zou CQ (2012). Alleviation of drought stress in winter wheat by late foliar application of zinc, boron and manganese. J Plant Nutr 175: $142-151$

33. Shehu HE, Kwari JD \& Sandabe MK (2010). Effects of N, P and K fertilizers on yield, content and uptake of $\mathrm{N}, \mathrm{P}$ and $\mathrm{K}$ by sesame. Int J Agri Biol 12: 845850.

34. Abbas GM, Khan Q, Jamil M, Tahir M \& Hussain F (2009). Nutrients uptake, growth and yield of wheat as affected by zinc application rates. Int J Agri Biol 11: 389-396.

35. Sebilo M, Mayer B, Nicolardot B, Pinay G \& Mariotti A (2013). Long term fate of nitrated fertilizer in agricultural soils. PNAS 110(45): 18185-18189.

36. Asad A \& Rafiq R (2000). Effect of Zn, $\mathrm{Cu}, \mathrm{Fe}, \mathrm{Mn}$ and $\mathrm{B}$ on the Yield Components of Wheat Crop in Tehsil Peshawar. Pakistan J Biol Sci 3: 161520

37. Khan UM, Qasim M \& Jamil M (2004). Effect of Zn on starch content of paddy and $\mathrm{Zn}$ content of soil, leaf and root of rice grwon in calcareous soils. Int $J$ Agric Biol 6(6): 1132-1135. 